\title{
FATHOM
}

\section{High culture and popular culture in Far from the Madding Crowd}

Culture savante et culture populaire dans Far from the Madding Crowd

\section{Peggy Blin-Cordon}

\section{(2) OpenEdition}

\section{Journals}

\section{Electronic version}

URL: http://journals.openedition.org/fathom/529

DOI: $10.4000 /$ fathom.529

ISSN: 2270-6798

\section{Publisher}

Association française sur les études sur Thomas Hardy

\section{Electronic reference}

Peggy Blin-Cordon, " High culture and popular culture in Far from the Madding Crowd", FATHOM [Online], 3 | 2016, Online since 30 April 2016, connection on 07 May 2019. URL : http:// journals.openedition.org/fathom/529; DOI : 10.4000/fathom.529

This text was automatically generated on 7 May 2019. 


\title{
High culture and popular culture in Far from the Madding Crowd
}

\author{
Culture savante et culture populaire dans Far from the Madding Crowd
}

\author{
Peggy Blin-Cordon
}

1 Much has been written to try and put Thomas Hardy in a category of writers. Some contemporaries held him in high esteem, others considered that he was quite unworthy of belonging to "The Great Tradition". In the early process of becoming a writer, Hardy probably yearned for this sense of belonging: belonging to the class of authors which he admired, belonging to a tradition which would turn him into a respectable author. Considering such intellectual ambitions, the highly Victorian dichotomy between high and low art seems to be quite relevant as far as he is concerned. Hardy's career as a novelist is fraught with such ambivalence, in so far as his fiction always oscillates between the two. In an era when literary means of production underwent substantial changes, Hardy witnessed and experienced the spread of mass media literature mainly thanks to the advent of serial fiction published in periodicals, and circulating libraries. The new way of consuming literature, as well as a widening readership penetrating more and more layers of Victorian society, contributed to the distinction between an elitist and a lowbrow culture: "All that can be said is that because of new commercial conditions the beginnings of a split between popular and cultivated taste in fiction is apparent" (Leavis 158). The marginalized culture is mostly described by Hardy's contemporaries as being dedicated to the sensational, and to the gratuitous and thrilling experience of strong emotions: "This shift in Britain from self-definition in terms of production to selfdefinition in terms of consumption makes leisure a problem as well as pleasure for the middle classes" (Daly 15).

2 Fame, and the subsequent freedom of being able to write progressively as he wished and to choose his publisher, could be considered as a motive strong enough for Hardy to write the eminently sensational and commercial Desperate Remedies, a fascinating case in point and his first published novel, in 1871. Leisure and pleasure are central in "sensation fiction", a genre flourishing in the 1860s: "[a] commercial atmosphere floats around works of this class" (Mansel 483). It is probably the best instance of what was then 
considered as lowbrow literature. Many things have been written on the subject which is now a perfectly respectable object of analysis, yet the "sensation novel" and its avatars (the Newgate novel, the bigamy novel) are considered as highly reprehensible for the Grundyite of that time, they supposedly only aim at the lesser educated:

Just as the Middle Ages people were afflicted with the Dancing Mania and Lycanthropy, sometimes barking like dogs, and sometimes mewing like cats, so now we have the Sensational Mania. Just, too, as those diseases always occurred in seasons of dearth and poverty, and attacked only the poor, so does the Sensational Mania in Literature burst out only in times of mental poverty, and afflict one of the most poverty-stricken minds. (Wise 269-70).

The genres considered as not suitable to belong to the literary canon mostly rely on unrealist trends and are considered as sheer entertainment.

Yet, pleasure is also one of Hardy's major aims when writing. Regardless of the notion of literary value, Hardy is intent on "writing a good story" ("A story must be worth the telling", F. Hardy 158) mainly to strike his reader, and the elements of his good stories often lie in such popular genres. But they also allow the author to convey subversive messages, at the same time aptly using other nobler forms he knows and handles perfectly well.

5 We may consider Desperate Remedies as a forceful attempt at being published, although it is much more than that. However, the repercussions of the choice of sensation fiction, so distant from Hardy's first higher literary aspirations, never totally fade away in his following novels. Writing his way towards respectability, his desire to entertain was often conveyed by the genre, in Desperate Remedies, in Tess, or Jude, and, of course, in the early Far from the Madding Crowd. Two books had already been written since the radical Desperate Remedies, and Far from the Madding Crowd stands at a literary crossroads in Hardy's career, after a sensation novel, and a pastoral. Many elements of the low/ highbrow dialectic present in Far from the Madding Crowd were to be recycled and improved in other novels, as we shall see when making comparisons. The early wish to maintain a disruptive discourse and his being torn between success and artistic uprightness, two notions sometimes barely compatible according to Victorian standards, did not make things easy for Hardy, and when the Cornhill asked him to write yet another novel, he found himself faced with a dilemma:

This was the means of urging Hardy into the fortunate course of hurrying a further production before he was aware of what there had been of value in this previous one: before learning, that is, not only what had attracted the public, but what was the true and genuine substance on which to build a career as a writer with a real literary message. For mere popularity he cared little, as little as he did for large payments; but having now to live by the pen [...] he had to consider popularity.

(F. Hardy 134-35, my emphasis)

6 Far from the Madding Crowd does contain elements of sensationalism, considered by the critics as "a fault". Many devices and techniques deriving from the genre can be found in the book. The example of the letter device is one of them, and illustrates this point. Its role is paramount in the novel, as is very much the case in Wilkie Collins's fiction. The examples are numerous: the Valentine hoax (Hardy 1986, 79), the letter by Fanny to Boldwood and then taken to Oak (82-3), the message from Bathsheba begging Oak to come to her rescue, the words written by Pennyways to Bathsheba to tell her that her husband is alive and among them (267). In addition, many chapters bear a title explicitly referring to them, so important are they in the narrative process of the novel: Ch. XIII "Sortes 
sanctorum: the Valentine" [the oracles of the holy writings], Ch. XIV "The effect of the letter", Ch. XV "The letter again". Just as in sensation fiction, the letter is not a mere cosmetic or stylistic device, it does affect the narrative structure of the book and truly helps the action unfold: there would be no plot without the Valentine, no suspense without Pennyways' message, and the love-hate relationship between the former farmer now become shepherd Gabriel Oak and the ex-milkmaid now become farmer Bathsheba is epitomized by the message she sends him, relying on feelings and regardless of hierarchy: "Do not desert me Gabriel" (111).

7 Many other sensational strings are pulled in the book. They rely on: Fanny's illegitimate child, the secret marriage of Troy and Bathsheba, the coincidences and missed opportunities such as Fanny's going to the wrong church on her wedding day, the dead but not quite dead Troy, the murder scene, and of course, the morally reprehensible sexual tension pervasive in several excerpts, a tension that Leslie Stephen takes so much care to eradicate in order not to "shock a young lady", according to his very words: “'Thou shalt not shock a young lady' was, he said, the first commandment he had to enforce" (Maitland 266).

The Cornhill was not Tinsley's Magazine (Tinsley had published Hardy's previous fiction: in volume form for Desperate Remedies, in monthly installments for Under the Greenwood Tree [1872] and A Pair of Blue Eyes [1873]), and the Cornhill readers were from a different social category than Tinsley's. The choice and acceptance by a new, more reputable magazine, and its respected and admired editor Leslie Stephen, himself a representative of the literary canon, represented a turning point in Hardy's career in general, but most specifically as far as the lowbrow/highbrow distinction was concerned. Indeed, the Tinsley brothers were more used to dealing with Collins or Braddon, whereas the Cornhill published Gaskell, Trollope and Eliot.

The way women are depicted is also quite particular to the sensation genre. Female protagonists are often portrayed as opposing types, for example strong-headed and black-haired Marian Halcombe and her antithesis the weaker and fairer Laura Fairlie in The Woman in White. In Far from the Madding Crowd, the focus is also on the disparity between the heroines, but once more, with a more ambitious purpose. Bathsheba affectedly "drop[s] the cloak, and forth tumbl[e] ropes of black hair over a red jacket" (Hardy 1986, 17). The negative Fanny, on the contrary, is a fair-haired girl, poor, modest, and innocent: "She [wears] [her hair] rather short, and packed away under her cap [contrary to Bathsheba who ostentatiously displays it] so that you would hardly notice it. [...] Real golden hair" (215). The colour of Fanny's hair also gives away the nature of Troy's relation to her, since he keeps a lock of it in the case at the back of his watch (209). Similarly, Bathsheba is a rather full-figured woman: "[Boldwood] saw her black hair, her correct facial curves and profile, and the roundness of her chin and throat" (93) whereas Fanny is said to be "a slim girl, rather thinly clad" (43), and contrary to bold Bathsheba, she is "A Timid girl" (as the title of Ch. VII tells the reader).

Such oppositions characterize male protagonists too. Oak and Troy have two contrasting tempers, as is explicitly stated: “Troy's deformities lay deep down from a woman's vision, whilst his embellishments were upon the very surface; thus contrasting with homely Oak, whose defects were patent with the blindest, and whose virtues were as metals in a mine" (Hardy 1986, 147). Yet the set of oppositions is a sensational pretext for Hardy to develop the character of Bathsheba and present the reader with a transgressive vision of femininity. Bathsheba Everdene is the evolution of Marian Halcombe insofar as the type 
she represents is used in order to introduce an even bolder version of Collins's character. Bathsheba is a woman working and earning her living, an independent and sensual woman living according to her desire and instinct, and, at least at one moment in her life, preferring the sexual object she sees in Troy, to a prison-like marriage with Oak. The highly dissident vision of woman jarring completely with Victorian prejudices is made possible by the subversion of the one-dimensional archetype of the sensation novel hypotext.

11 Troy also stands for the traditional sensational archetype of the villain. Without being as a fiendish as Collins's Count Fosco or even Hardy's Manston in Desperate Remedies or William Dare in A Laodicean, he often is associated with the devil ("You juggler of Satan! You black hound!", Hardy 1986, 182) and stands for the trickster in the novel, a master of disguise, relishing mises en scene (the sword exercise, the play), playing hoaxes on Boldwood, although "bad as [he is], [he is] not such a villain as to make the marriage or misery of any woman a matter of huckster and sale" (182). The appearance of Troy quite late in the novel, when the reader is set on the track of Gabriel's courting of Bathsheba, cannot but appear as the main hindrance to Oak's design. This is reinforced by the fact that the serialization of the novel enhances the theatrical quality of such an appearance since the character of Troy is only very progressively brought into the novel, which creates tension and suspense as the reader gradually realises the demonic aspect of his personality.

12 However, as is the case for other devices belonging to popular genres in Far from the Madding Crowd, such a generic topos is never fully exploited by Hardy, in a provocative and powerful reliance on genres which do not belong to the dominant. Indeed, the opposing types never clash in Far from the Madding Crowd, and the much awaited and cathartic confrontation between Troy and Oak never really occurs. Furthermore, their wooing the same woman proves to be much more complex than the traditional scheme since a third character confusingly appears to form not a pair but a triangle of suitors for Bathsheba. Likewise, Bathsheba and Fanny never get to fight for Troy's love and Bathsheba never gets the chance to confront her rival since Fanny dies, ironically much to her disappointment: "If she had only lived, I could have been angry and cruel towards her with some justification; but to be vindictive toward a poor dead woman recoils upon myself" (Hardy 1986, 229).

13 Archetypes working in pairs actually represent a well-known topos of yet another popular genre - melodrama:

[s]ensationalism of every kind seemed most readily suited to the tastes and energies of the new reader, exhausted by a day of labour and untrained in those disciplines of thought and feeling which help the reader to respond to low-key exploration of experience. [...] The model for both popular fiction and theatre was melodrama, with the result that popular plays and cheap fiction bore a close resemblance to each other. (Hamer 16)

14 Melodrama also prevails in the novel, see the coincidences, the impressive manifestations of nature (the storm, recalling the storm in Desperate Remedies, the fire, evocative of the burning Three Tranters' Inn in the same novel). Melodramatic stylistic techniques are also used to structure some passages such as in Ch. XL: "On Casterbridge Highway".

This episode is written in a style conveying the pain endured by Fanny as she counts the posts separating her from her destination. We suffer with her on her own way of the cross, in a scene clearly verging on melodrama. Fanny's predicament is made vivid thanks 
to this technique, and this vividness is enhanced by striking sentences such as "during the effort each breath of the woman went into the air as if never to return again" (Hardy $1986,205)$, a heavy style triggering pathos. The syntax is simple, the vocabulary repetitive "she passed five more", "she passed five more", "she passed them", "I'll pass five more" (205), until the scene ends in similar paratactic style with the accepting sentences, as if failure could come as a liberation, for both the woman and for the sympathetic reader: "Hopelessness had come at last. No further! She whispered, and closed her eyes" (205). What is striking first is that the object of our compassion is the figure of an outcast, a fallen woman, not worthy of empathy according to Victorian standards. In addition, as always with such a radical technique in the novel, this pathos is harshly counterbalanced when the reader learns that the helping dog has been driven away by stones. The cruelty and cynicism of the deed transforms melodrama into the initial stages of tragedy, a noble genre also very present in the book. Such an association lay at the heart of Hardy's further generic experimentations in The Return of the Native (Hardy 1999) most of all, with the character of Eustacia for instance, a "perfectly imperfect character" and an unstable mix of the tragic and the melodramatic. She and Bathsheba use the same melodramatic monologues as they indulge in fits of passion - see Bathsheba's jealousy when Troy kisses the dead Fanny, “Don't kiss her, kiss me" (Hardy 1986, 230) - and when she can't hold it against Fanny because she is dead, she enters a hysterical trance and expresses her frustrated anger in a histrionic soliloquy:

"O, I hate her, yet I don't mean that I hate her, for it is grievous and wicked; and yet I hate her a little! Yes, my flesh insists upon hating her, whether my spirit is willing or no! ... if she had only lived, I could have been angry and cruel towards her with some justification; but to be vindictive toward a poor dead woman recoils upon myself. O God, have mercy! I am miserable at all this!" (Hardy 1986, 229)

Hardy was to further exploit the tragic possibilities of melodrama using the same technique for Eustacia, to express in a speech her solitude and frustration, yet, in a more radical way since the heroine also conveys the injustice and fatality the world imposes on her:
“I can't go, I can't go!" she moaned. "No money: I can't go! And if I could, what would comfort me? I must drag on next year as I have dragged on this year, and the year after that as before. How I have tried and tried to be a splendid woman, and how destiny has been against me! ... I do not deserve my lot!" she cried in a frenzy of bitter revolt. "Oh the cruelty of putting me into this imperfect, ill-conceived world! I was capable of much; but I have been injured and blighted and crushed by things beyond my control! o how hard it is of Heaven to devise such tortures of me, who have done no harm to Heaven at all!" (Hardy 1999, 346)

17 We may consider Eustacia's plea as the prolongation of Bathsheba's monologue. Such a technique inherited from stage melodrama is often used by Hardy when his characters, prey to violent feelings, are on their own, and the author needs them to express their sentiments in order to share them with the audience. Therefore, blurring generic borders and partially exploiting the traditional codes of popular genres allow Hardy to make a literary compromise, and to initiate a transition with other more respectable genres, tragedy and the pastoral.

18 A comparison with a later novel, The Mayor of Casterbridge (Hardy 1994a), in which the border between the genres is strongly asserted and the delimitation of the codes much more visible, may be enlightening in order to understand how such radical devices are toned down in Far from the Madding Crowd. The mark of the sensation novel appears very early in the book when Henchard sells his wife and child, yet another event which echoes 
Far from the Madding Crowd when Boldwood, in a negative yet equally sensational scene, tries to bargain for Bathsheba's and then Fanny's hand. Henchard wins them back, in Chapter XIII: he is finally reconciled with Elizabeth Jane and Susan and marries the latter again, ostensibly making amends for his past mistake. The family is (re)united and in a word, all is well that ends well. Here, the border of the sensation novel is clearly delimited; still, it does not coincide with the closure of the book. The happy outcome will not last long: indeed, from this moment on, the sensation novel completely recedes in order to give way to the tragic, until the climax of the death of Henchard, who never can reconcile with his step-daughter and dies alone at the end of the novel. In Far from the Madding Crowd, the generic borders are much less clear-cut since the sensational episodes are scattered throughout the book, though they seem to get more and more frequent as novel draws to a close.

Other strategies come to counterbalance this blatant use of the techniques of popular literature, and place Far from the Madding Crowd in a more ambitious literary perspective. First, we can point out Hardy's extensive use of allusions. A lot has been said on the subject, notably by Marlene Springer. The variety and profusion of erudite references, direct or indirect, to famous writers, poets, novelists, and to the mythological or the biblical creates an immensely rich and learned hypotext which ceaselessly shows Hardy's wide knowledge of all kinds of arts, of literature, but also of painting and music. This propensity towards allusion is sometimes detrimental to the narrative itself, sometimes even pedantic. Yet, once more, Hardy does not discriminate against the lesser educated, since his quotations also rely on popular beliefs, folk tales and songs, on easily identifiable myths, on well-known biblical episodes, which he turns into comical moments such as with the "Cain" anecdote 2 .

Generically speaking, popular sensation fiction and melodrama mix with genres held in a higher esteem by the critics. From the very first pages, the novel obviously sets a pastoral tone. If we bear in mind the fact that the time in the novel, serialized in the Cornhill, corresponds to the months when each installment was issued, this increases the proximity of the readership to the lives of the rustics, busy with their farm work (such as sheep shearing in June, or oat harvesting in August) central to the pastoral theme. When he wrote the novel Hardy was already famous for being good at depicting rural life. He was praised for this talent as early as Desperate Remedies since many critics pointed out that his best written scenes were those "fixing phases of peasant life" (Anon. 1871, 481-83) (like the cider making in Desperate Remedies, Hardy 1998, 124-26). The influence of the critics persuaded him to write the pastoral Under the Greenwood Tree (Hardy 1994b), itself much appreciated by Stephen, which may have influenced his decision to publish Far from the Madding Crowd.

21 The pastoral genre is present both in the opening and in the closure of Far from the Madding Crowd, since the last chapters also deal with the relationship between Gabriel and Bathsheba, treated on a mode drastically differing from the melodramatic undertones of Bathsheba's passion for Troy and their elopement and secret marriage. In the chapter entitled "Beauty in Loneliness", the reader witnesses a thorough generic shift when the novel comes back to the pastoral and the description of the reasonable union between Bathsheba and Gabriel. This is what Stephen probably saw in Under the Greenwood Tree, ideal rural life and love transactions based on economic considerations. Indeed, Hardy presents the relationships between the protagonists mainly as financial arrangements. Bathsheba needs Oak for the work and skills he can provide on her farm. Every time her 
wealth is at stake, the narrative renews their relationship. At the end of the novel she wonders how she is going to cope without his help ("Since Troy's death Oak had attended all sales and fairs for her, transacting her business at the same time with his own", Hardy $1986,301)$. And when he deserts her (as she phrases it), she eventually agrees to become his wife in a marital agreement which resembles more a compact than the outcome of mutual love. The union does seem a little contrived, lacking "pretty phrases and warm expressions" (303), and we find a mention of the word "business", some lines before Oak's mild declaration (302). Hardy previously presented us with a passionate woman, who tries to live by her book. With this lukewarm version of Bathsheba, he confuses the reader who is much more used to an over determined conception of gender. At the end of Far from the Madding Crowd, the uncompromising melodramatic genre, with passionate, desperate, hopeless, unrequited love stories, fails to prevail and to end the tale, probably because it would have forced an unhappy ending on the novel. Although Troy does come back to Bathsheba as much for the financial position she guarantees as for his deep feelings for her, at least his motivation seems much more passionate than Oak's in the last chapters. While Troy, a carefree man with hedonist inclinations, indulges in the pleasures of liquor, oblivious of the impending storm outside, Oak, a man of duty, will always be there to protect his mistress's wealth.

Therefore, all in all, the novel comes full circle. The pastoral opening, focused on Oak and Bathsheba's social disparity, is full of tragic and melodramatic possibilities. But problems are eventually solved thanks to Oak's accumulated goods finally allowing him to meet Bathsheba's standards. The transgressions allowed by melodrama and sensation fiction, which constitute the consequences of a pastoral event, come as powerful and indispensable parentheses in between highly pastoral moments. Those parentheses allow Hardy to write an idiosyncratic vision of life he was later to develop more freely. But until then and in spite of his boldness, all is well that ends well: in The Return, in The Mayor, this will no longer be the case. In Far from the Madding Crowd "all romances end at marriage", and the happy end happens willy-nilly, the last concession Hardy makes in order to conform, in an eclectic, unstable text constantly wavering between the marginal and the dominant.

\section{BIBLIOGRAPHY}

Anon., "Belles Lettres and Contemporary Literature", The Westminster Review 47 (1875): 265-276.

Anon., Review of Thomas Hardy, Desperate Remedies, Spectator (April 22, 1871): 481-483.

Daly, Nicholas, Sensation and Modernity in the 1860s, Cambridge \& New York: Cambridge University Press, 2009.

Hamer, Mary, Writing by Numbers, Trollope's Serial Fiction, Cambridge: Cambridge University Press, 1987.

Hardy, Florence Emily, The Life of Thomas Hardy: The Later Years of Thomas Hardy (1892-1928) (1930), London: Studio Editions, 1994. 
Hardy, Thomas, Desperate Remedies (1871), Harmondsworth: Penguin Classics, 1998.

Hardy, Thomas, Under the Greenwood Tree (1872), Harmondsworth: Penguin Popular Classics, 1994.

Hardy, Thomas, Far from the Madding Crowd (1874), ed. Robert C. Schweik, New York \& London: Norton, 1986.

Hardy, Thomas, The Return of the Native (1878), Harmondsworth: Penguin Classics, 1999.

Hardy, Thomas, The Mayor of Casterbridge (1886), Harmondsworth: Penguin Popular Classics, 1994.

Leavis, Queenie D., Fiction and the Reading Public (1932), London: Chatto \& Windus, 1965.

Maitland, Frederic William, The Life and Letters of Leslie Stephen, New York: G. P. Putnam's Sons, London: Duckworth and Co., 1906.

[Mansel, H. L.], “Sensation Novels”, The Quarterly Review 113 (April 1863): 481-514.

Springer, Marlene, Hardy's Use of Allusion, London: Macmillan, 1983.

Wise, J. R., "Belles Lettres”, The Westminster Review 30 (July 1866): 268-280.

\section{NOTES}

1. "[T] $]$ he fault in Far From the Madding Crowd is undoubtedly its sensationalism" (The Westminster Review 1866, 266). The novelist is also compared to M. E. Braddon at one point.

2. See chapter $\mathrm{X}$, in which Gabriel explains to Bathsheba:

“'How did Cain come by such a name?' asked Bathsheba.

'Oh you see, mem, his pore mother, not being a Scripture-read woman, made a mistake at his christening, thinking 'twas Abel killed Cain, and called en Cain, but 'twas too late, for the name could never be got rid of in the parish. 'Tis very unfortunate for the boy."' (Hardy 1986, 67)

\section{ABSTRACTS}

The fluctuation between highbrow and lowbrow literature seems to be at the heart of Thomas Hardy's career as a novelist, torn between success and artistic uprightness as he was. The early Far from the Madding Crowd (1874) represents a case in point of such a dilemma. Indeed, the spread of serialised literature, mainly thanks to the advent of sensation fiction, enabled Hardy to "write a good story", and sensational and melodramatic episodes in Far from the Madding Crowd show many similarities with other lowbrow novels of the time, full of unexpected twists. Even though the dominant genres of the pastoral and the tragic prevail in Far from the Madding Crowd, proving that Hardy initiated a transition with other more respectable genres, lower forms allowed him to convey a disruptive discourse within the book, and to create an original mix between high and popular forms which will later become one of his hallmarks.

L'ambiguïté entre culture savante et culture populaire semble se trouver au cœur de la carrière de Thomas Hardy le romancier, tiraillé entre succès public et respectabilité artistique. Far from the Madding Crowd (1874), un de ses premiers romans, est un bon exemple d'un tel dilemme. En effet, le succès grandissant de la littérature en feuilletons, en grande partie dû au triomphe du 
«sensation novel », permet à Hardy d' «écrire une bonne histoire », comme en attestent les épisodes mélodramatiques et ceux relevant du « sensation novel » dans le roman, qui présentent de nombreux points communs avec d'autres romans de l'époque appartenant à la littérature populaire pleine de rebondissements. Même si les genres de la pastorale et de la tragédie l'emportent dans Far from the Madding Crowd, attestant du fait que Hardy entame là une transition certaine avec une littérature dite plus respectable, la littérature de masse lui permet d'apporter un discours subversif dans son roman, et de créer un mélange original entre des genres littéraires populaires et nobles, mélange qui deviendra plus tard une de ses marques de fabrique.

\section{INDEX}

Mots-clés: culture populaire, érudition, savant/populaire, genre littéraire, roman à sensation, mélodrame, pastoralisme, tragédie

Keywords: popular culture, highbrow/lowbrow, genre, sensation novel, melodrama, pastoralism, tragedy

\section{AUTHOR}

\section{PEGGY BLIN-CORDON}

Peggy Blin-Cordon, holder of the "agrégation" in English Language and Literature, is a Lecturer at University of Cergy Pontoise, where she teaches literature and translation. A founding member and the treasurer of the FATHOM association (French Association for Thomas Hardy Studies), she wrote a thesis on generic experiments in the novels of Thomas Hardy. She specialises in Hardy and literary genres and also works on the influence of the publishing practice on $19^{\text {th }}$ century fiction. 